\title{
Rethinking Institutional Frameworks in Conservation and Governance of Forests in the Background of FRA in Kerala: From Exclusion to Inclusion
}

\author{
K H Amitha Bachan* and Maya $\mathrm{M}^{+}$
}

\begin{abstract}
The forward and backward linkages between conservation, governance and people's initiatives have been a widely accepted paradigm in the domain of sustainable forest management. Forest Rights Act, 2006, is remarkable as it is the only law which is based on the principles of inclusion by recognizing the decision making authority of hamlet level Gram Sabhas in conservation. This paper looks at the existing institutional frameworks for conservation, i.e. forest and its resource management including land tenureship and to address societal needs of ethnic communities. The analysis is done within the backdrop of the assigned roles of hamlet level Gram Sabhas in FRA with special focus on the Anamalai region, Central Kerala within the distribution area of Kadar (notified particularly vulnerable) ethnic community. The progress of FRA implementation in this region has been discussed as a measure of the shifting of exclusive institutional frameworks to an inclusive one.
\end{abstract}

Keywords: Forest Rights Act (FRA) 2006, Community Forest Resource (CFR), Gram sabha, Exclusion, Inclusion, Kadar, Ethnic communities, Conservation

* MES Asmabi College, Kodungallur, Kerala, India \& Fellow, Western Ghats Hornbill Foundation. amithabmes@gmail.com

+ Christ University, Bengaluru, India; maya.m@christuniversity.in 


\section{Introduction}

Conservation of natural resources and its management has been a growing concern at the international, national as well as at micro level community settings. An ecological consciousness in this regard at the political and policy-making level in India came up during the 1980s. The new environmentalism recognised the inefficiency of a market-driven, capitalist-oriented economic pursuits to ensure environmental sustainability. A series of laws aimed at the protection and management of wildlife has been initiated during this period. However, all these initiatives operated within an exclusionary framework where the emphasis was on framing and implementing certain rules and protocols. The decision making has been restricted to bureaucratic institutions. It did not look at the actual functional dynamics in translating these ideals into action. Even in the cases where participatory approaches were promoted, the decision making was paternalist, and the role of the community was to carry out activities that are assigned to them by the authorities.

The Forest Rights Act (FRA) 2006 is remarkable in this context as it is the first law of its kind that perfectly blends elements of governance and conservation. It provides democratic space based on inclusionary principles. It ensures individual rights as well as community forest resource (CFR) rights to the forest dwelling communities. As per this act, the hamlet level Gram Sabhas are entrusted with the power to control, manage and monitor its natural resource base within the traditional boundaries of villages in a sustainable manner. The provisions of community rights envisaged in this act reiterate the necessity of the symbiotic relationship and cooperation of forest-dependent people as a community over their habitat. It aims at the empowerment of the right holders for the conservation and protection of forests, wildlife and biodiversity as well as their natural and cultural heritage (GoI, 2007).

As per the provisions of FRA, hamlet level Gram Sabha is the ultimate decision-making body having authority to make decisions concerning the use and management of Community Forest 
Resources (CFR1). The governing powers of the Gram Sabha (hamlet level GS2) include the formation of CFR Management Committee (CFRMC3) and preparation of CFR Management Plan (CFRMP4). However, there exist multiple levels of institutional structures of governance in any tribal setting. At a functional level, any community gathering to facilitate activities at hamlet level can be considered as a Gram Sabha. The question is what kind of a Gram Sabha can be instrumental in the management of forest, management of resource and in materialising societal needs. Management of forest in general means keeping the quality and extent of ecosystem intact including land tenureship. Resource management means ensuring the sustainable harvest and use of resources which the community depends upon including NTFPs. Societal needs include the socio-cultural day to day needs of society as well as requirements in tune with the modern development paradigms like housing, sanitation and the like.

This paper looks at the different kinds of institutional mechanisms that operate in an ethnic community setting and their roles in natural resource management and conservation. The reference point for the arguments is the landscape of Anamalais in Central Kerala which is home to Kadar community, one of the five primitive tribal groups in Kerala.

The central question is to see what kind of an institutional framework can effectively address the issues of conservation and development by imbibing the spirit of the principles of inclusion. The generic use of the term inclusion in social policies is not enough. The question is how it moves from the level of policy discourses to the level of action. The extent of the role played by each of these institutions needs to be assessed to find out the actual functional institutional framework that would be effective at the micro level. This could be a measure of the role of the traditional institution and the state in ensuring conservation in action. Such an exercise can provide a thought on how newly formed FRA Gram Sabhas can function to materialise inclusive governance and

\footnotetext{
1 Sec 3(1) i and Section 5 of the Forest Right Act 2006.

${ }^{2}$ Sec 2(g) and 2(f) of the Forest Right Act 2006.

${ }^{3}$ Sec 4(e) of the FRA Amended Rules 2012.

4 Sec 4(f)\&(g) of the FRA Amended Rules 2012.
} 
conservation. This can also provide insights on possibilities of merging exclusionary Gram Sabhas defined by the state with the traditional community institutions.

\section{The Multiple institutional frameworks of Governance and conservation at Hamlet level}

The multiple institutional frameworks in the socio-political sphere of a tribe in Kerala can be divided into three viz., political, bureaucratic and traditional. The most important is the political institutions of democracy. It refers to the Gram Sabhas constituted under the three-tier decentralisation system backed by the $73^{\text {rd }}$ amendment to the Constitution. This is the Ward Sabha including 700-1000 adult members of a ward and is unusual to the concept of Grama Sabha in other states. Selection of this governing body is based on proportional representation through the general election. This will have an elected member to the Grama Panchayath Committee, and usually, it is a representative of a dominant political party of the region.

The kind of Gram Sabhas constituted by various Government Departments and non-governmental agencies for policy implementation are bureaucratic in nature and functioning. For instance, the Kerala Tribal Department recognized tribal Gram Sabhas called 'oorukoottams s' (hamlet level gram sabha) headed by mooppans (chieftains) as a necessary institutional framework to reach out the community and to channelise its development initiatives and to select beneficiaries. Similarly, Department of Forest under its Joint Forest Management (JFM) or Participatory Forest Management Scheme (PFM6) has created community structures Vana Samrakshana Samitis (VSS) in the territorial forest divisions and Eco-Development Committees (EDCs) in the Protected Areas (PA) including Wildlife Sanctuaries, National Parks and Tiger Reserves. The concerned VSS/EDC operates as

${ }^{5}$ Oorukootam : colloquial term used among tribals. Ooru means habitat. From Tenth Five Year Plan onwards, Government has recognized these indigeneous forums of tribals.

${ }^{6}$ National Forest Policy 1988 \& Govt. of Kerala Order No. GO(MS)08/98 Dt. 16.01 .1998 
Gram Sabhas regarding the implementation of activities through this department.

Many other departments of the state operate at the ethnic community level through setting up similar kind of 'selected' groups chiefly to identify beneficiaries, for eg. Health Department, Department of Primary Education, ICDS and the like. All these kind of bureaucratic institutions claim their operations as 'participatory' and inclusive. But in practice, they offer not more than 'integration' where the people from the community are integrated to do some activities that are designed and decided by the state or bureaucracy. Most of the NGOs and the political parties work in the same manner through setting up beneficiary groups and governance structure. All these reflect the colonial legacy of the exclusionary framework. Recent shift into the participatory framework is questionable, and in practice, it is only an 'integration' rather than 'participation'. The 'participation' happened only in the theoretical frame and not in structural framework and hence in practice (Maya, 2013).

At the same time, there is a traditional institutional framework within the community to manage the social and cultural life of the people. It is restricted to the ethnic community members only. Neither has it been recognized as a 'Grama Sabha' or 'Oorukoottam' by the state or the bureaucracy and even the community level.

\section{Forest management and Institutional frameworks}

The major concern in forest management is about the quality and extent of forest cover. The focus is on the loss of forest area. Forest degradation results in alteration of forest structure, biodiversity loss and alteration of the forest ecosystem. This section is an attempt to historically analyse the role played by the various institutional structures in this regard which is based on the narratives collected from the ethnic tribal community members.

The dwindling of forest cover in Anamalais started with the establishment of tea plantations during the 1870s and 1880s. Before this phase, the forests were under the tenureship of different communities in the area like Kadar, Malayan, Malamalasar, Muthuvan and Pathimalassar. The forest was intact and un-fragmented during that time in this entire landscape. The first massive forest 
conversion for the development of tea plantations was in Valparai and Nelliyampathy. It was backed by the predominant exclusive forest policy of 1878 by the colonial administration. The forest law of 1927 was based on the exclusive principle that forest-dwelling communities are not efficient to scientifically manage forest resources. Based on this law, the state declared Parambikulam as a reserved property of the state and started converting forest patches to forest (teak) plantations. These processes affected the life and habitat of the tribal communities in these regions and ultimately hindered conservation. Studies show that the landscape of the forests was transformed from the dark evergreen forests to plantations of tea, coffee and spices (Varma et al. 2005; Sekar and Ganesan 2003; Raman and Mudappa 2003; Mudappa and Raman 2007). It is evident that the initiatives for gradual deforestation were a part of political and bureaucratic decisions. In all these cases, the decision was taken by the state based on the existing exclusionary laws and was facilitated by the bureaucratic institutions.

Conversion of forest land for other purposes not only affected the quality and extent of forests but also altered the life habitat of the tribal communities inhabiting in this region. It made possible the entry of bureaucratic institutions. The community as traditional institutions always opposed such massive conversions. The resistance from the community was in terms of moving away from these external interventions. A section of the community shifted to other parts of the forest away from the estates and plantations. On the other hand, it was necessary for the estates/plantations to have enough human resources. This felt need initiated the entry of bureaucratic institutions like the Forest department to this region. They engaged people for labour, for cutting trees, logging, and other plantation works. The community was motivated by material benefits and a part of the community, thus involuntarily became part of the decisions of the state.

The construction of the Parambikulam Tramway by the British (1901-63) for extraction of timber was another politico-bureaucratic intervention in this region. The forest Tramway cut through forests of the Kadar and some Muthuvar villages of those days, fragmenting and changing the composition of the natural habitat due to forestry 
operations (Manish Chandi, 2008). The construction of the Anamalai road which started in 1942 from Chalakkudy to Valparai further complimented the incursions into the rainforests of the Vazhachal/Charpa regions bringing more changes to the forests and indigenous tribals of the region, chiefly the Kadar and the Mala Malasar (ibid).

The next phase of intervention was for hydroelectric projects by Kerala State Electricity Board (KSEB) with its bureaucratic framework. After the construction of Poringalkuthu Dam in 1957 another five large dams - The Parambikulam group of dams viz. Thunakadavu, Peruvaripallam and Parambikulam in 1958, The Upper Sholayar in Tamil Nadu (1966), The Kerala Sholayar (1966) and the Chalakudy River Diversion Scheme meant for the irrigation of 14000 hectares of land were constructed. These constructions have blocked the river at seven places, and thus the river has lost its continuity affecting the tribal communities who used to live on its shores. Treaties like Parambikulam Aliyar treaty for diversion of the waters from the Parambikulam group dams, Sholayar dams. Water diversion from dams like Neerar of the Periyar river to Tamil Nadu in the east and from the Poringalkuthu to the Idamalayar in the Periyar basin to check the salinity intrusion in the industrial areas of Periyar have seriously affected the ecology and biodiversity of this area.

Along with these the tribal communities too were displaced from their original habitat that was submerged under the dams to the regions where they now inhabit. Bureaucratic institutional structures were efficient enough to extract enough human labour by luring a section of the community with material prospects. The community still resisted such changes subtly by finding alternate spaces within the forest.

The planned intervention strategies of the government in the postindependence period were also detrimental to affect the symbiotic relationship between community and ecosystem. The introduction of cash crops by replacing the food crops resulted in major changes. Earlier times, the ethnic communities of this region viz., Muthuvan, Malayan and Kadar together owned the land. The pattern of agriculture was oriented towards food crops, and multi-cropping was the practised. Although Kadar as a community were not 
agriculturalists, in the Valparai region they were associated with the other communities. They followed a complex tenureship in relation to farming activities. The collection of some commodities like mango, tamarind, firewood, medicinal plants were given to certain groups within the community. The decision was taken at the community level. The streams and water bodies were also considered as common property. The forced, involuntary displacement of communities for estates, plantations and hydroelectric projects without compensatory provision of land; land policies and the introduction of cash crops shifted the community orientation towards the needs of markets.

It is evident that the history of political and bureaucratic interventions in Anamalais is, in fact, the history of land alienation of tribal communities in this region. The exclusionary frameworks of forest management seriously affected the quality of the forest. The post-independence strategies like 'grow more' campaigns supported encroachment of people to forest areas for cultivation and these patches were gradually converted to revenue land. In the remaining (recorded) forest area, the forest department started softwood plantations to support industries. All rich evergreen forest areas including many fragile regions were converted into teak plantations especially in Parambikulam region, and a large chunk of all territorial regions were converted into mono-cultural softwood plantations. Before the beginning of planting teak, there was a massive clearing of forest for which state employed outsiders. So far it was the complexity of the forest areas that desisted migration from the mainland and the ethnic communities remained secluded. Thus, the incursion of people from the mainstream to forest areas was also assisted by the politicobureaucratic strategies.

Another way in which the administration created space for mainstream people was through tongya cultivation in the 1970s. Here, people were allowed to grow short-term tuber crops like tapioca in plantations with the condition that they would take care of the plants in the plantation. Tongya cultivation was not to help the local communities but assisted the migration of mainstream population. It had wide-ranging consequences in terms of conservation of land and forest. Tapioca cultivation in the slopes 
will result in soil erosion (Gadgil report, 2011, Kasturi Rangan, 2013 reports). During this period, there was no strong measure for the protection of wildlife. The plantation workers and tongya cultivators began hunting wild animals contributing to the history of poaching in this region. By this time, the ethnic communities were a silent minority.

Selective felling in rich evergreen forests was promoted by the state to feed the growing plywood industries in Perumbavoor and nearby regions in the 1970s. It adversely affected the pristine nature of primary forests. So it is evident that the concept of untouched forest within the primary forest is a mere illusion. The forest management tactics of the state simplified the complex nature of forest thereby assisting outside forces to creep into the forest areas. Such politico-administrative strategies not only altered the extent and quality of forest but enhanced issues of hunting and poaching. The gravity of the issues resulted in a strong environmental consciousness in the 1970s and 80s both at the political level and also among civil society.

The state changed its strategies towards forest conservation and newer policies were formulated like the 1972 wildlife protection act and national forest policy of 1988. It was realized that, for managing the complexity of natural forests, the knowledge and skill of the ethnic communities is a necessity. All kinds of effective conservation activities require inputs from the ethnic community. Integrated initiatives like Participatory Forest Management schemes were an outcome of such a realization. However, the extent of participation in such schemes was limited to the involvement of people in activities. Although termed participatory, it was integrated projects with no voice for the local communities in the planning phase.

Assisted Natural Regeneration (ANR) is a scheme envisaged to plant natural species to aid natural regeneration. It requires a specific group of plants suitable for specific regions depending on the status of regeneration and species requirement. But a deeper analysis of the activities of ANR would reveal the fact that in most cases, the department through conveners has decided to plant few fast growing trees without identifying the indigenous varieties suitable to that particular landscape. The methodology adopted 
was again based on exclusionary principle. To plant a single seedling, they have to clear one square meter. This scheme aimed to generate work and revenue, but by not limiting this activity to the degraded areas and by extending it to the primary forest areas, this had an adverse impact. The role of community in this scheme was to provide labour. However, the concept of PFM has given some serious stake to the ethnic community and this had an impact on ANR. In some areas, people started identifying proper areas with their local knowledge. They have started growing natural seedlings using the knowledge which was not available with the authorities. At the same time, there was no diversification of forestry work for the ethnic communities apart from fire line management or planting.

Another attempt by the forest administration was the planting of cane in evergreen forests in areas near Vazhachal. This requires the removal of 30-70 seedling from an area to plant one cane seedling (Perception of tribals from Malakkappara ). To make $1 \times 1$ platform, more area will be destroyed. As a scheme, cane planting was successful. But the perception of ethnic community is that cane planting is not good as it affects the availability of certain NTFPs in that region and the natural regeneration of the forest. At the same time, they require employment opportunities also.

The forest department has projects for the value addition of the products collected by the tribals so that they would get maximum profit by retaining their traditional source of livelihood. This would also help to reduce the encroachment of external people into the forest and their exploitation. The project for medicinal plant conservation and making value-added product through tribal VSS in Chalakkudy forest division (2008-09 to 2013-14) was under the financial assistance of National Medicinal Plant Board. In the regions having value addition, pressure on harvest is reduced.

The community-based hornbill conservation project was initiated by the Western Ghats Hornbill Foundation with the aim of developing a long-term conservation strategy for the hornbills and their habitat in this region with the active support of the Kadar tribe. It was an effort appreciated by other stakeholders in the region. The hornbill watchers ensure the sustainability of these birds by assessing the availability of hornbill nesting trees, nest 
characteristics, habitat details and threat factors. It envisages strengthening of ongoing participatory conservation activity in the Vazhachal forest division with the support of forest department, Kadar tribe and their community groups

In the Parambikkulam, Kadar are employed in the tiger conservation project. Kadar is the only tribal group in the region who knows each stretch of the rainforest. Although a few Malasar work for tiger monitoring, they say that they will not go to the interiors without a Kadan with them. The relationship between the Kadar and the forest has been effectively used in Parambikkulam by the forest department for tiger monitoring. They document the presence of tigers, the measurement of tiger claws, the location in a notebook and submit their periodic reports to the forest officer.

With the introduction of Participatory Forest Management (PFM) scheme, there was a greater involvement of ethnic community for the conservation of forest and biodiversity. But they had a very limited role during the decision making and strategizing part of activities. Hence it was far from being inclusive.

\section{FRA Implementation among Kadar}

The Scheduled Tribes and other Traditional Forest Dwellers (Recognition of Forest Rights) Rules, 2007 explains the formation and functions of Gram Sabha for the implementation of Forest Rights Act. The Gram Sabha has to constitute a Forest Rights Committee with elected members. It has to initiate further the process of determining the nature and extent of forest rights, receive and hear the claims relating to it, pass a resolution on claims on forest rights after giving reasonable opportunity to interested persons and authorities concerned and forward the same to the Sub-Divisional Level Committee. They also have to constitute Committees for the protection of wildlife, forest and biodiversity, from amongst its members; monitor and control such committee in preparing a conservation and management plan for community forest resources in a sustainable manner (GoI, 2007).

FRA implementation in Kerala was initiated with the focus being given to individual rights. There was a verification process initiated by revenue and forest department where in actuality, it has to be done by FRC (Forest Rights Committee). There are cases where 
claimants did not receive the rights over the claimed land but given rights over the land on which they had been issued titles earlier. No hearing was done in this area although there is a provision to allow GS for reconsideration. However, no documents support this.

The Forest Rights Act had the provisions for claiming the Community Rights (CR) and Community Forest Resource Right (CFR) and with the conviction that the rights of the indigenous communities or any resource-dependent communities are based on their collective freedom to access common resources, its management and decision making. As per the Forest Rights Act (2006), the ultimate decision-making units with respect to the conversion of the forests or Community Forest Resource Areas and their habitats are the Grama Sabha's (GS). So the power has to be shifted from the already mixed Gram Sabhas and legally assigned to the Tribal 'Oorukoottams' in Kerala. However, the state could not provide a single Community Claims under FRA Act until 2012. Very few claims were settled and no decision making functional bodies CFR Management Committees had been constituted.

Community Rights Claims under FRA was mainly made only with respect to NTFP collection and not on Community Forest Rights. No resource mapping was initiated. The extent of awareness was also not available. The lack of clarity among officials in charge and the forest dwellers were affecting the implementation of FRA in its infancy. The missing thing was a guiding force for claiming rights (Bachan, 2014).

Interaction with the community and tribal promoters reveal some of the problems faced by people in claiming their FRA rights. Sometimes, people from more than one settlement might be depending on the same resource area. Some NTFP collecting communities are residing in revenue land. They have land ownership for their land but authorities not allowing them to claim community rights. But as per the provisions of the act, such communities, if they depend on the forest for livelihood can claim community rights.

The act clearly states that Forest Rights Committee (FRC) members should consist of members from the community itself, and at least one-third of the members should be women. But in practice, in 
some areas, there exist a common FRC committee for more than one settlement. Some of the FRC members do not know that they are FRC members and their duties (ibid).

No serious concern was given to the formation and recognition of Gram Sabhas as statutorily designated authority under FRA. It was considered as one among the multiple hamlet level gatherings or beneficiary bodies under various departments like Forest, Tribal, Panchayat and the like.

It was in this context, that the Western Ghats Hornbill Foundation started awareness programs and campaigns on CFRs during 2009. Claims were made for CRs and CFRs in nine villages in Vazhachal Forest Division including eight Kadar and one Malayar villages in 2010-11. The Hornbill Monitoring team of Kadars facilitated the Gram Sabhas in empowering them for resource use mapping and demarcating the area. This was through holding GS meetings, discussions, a listing of CRs (NTFPs, fish, firewood, cattle grazing and other resources), mapping, and support to FRCs and GS for preparing and filing claims and collecting evidence. The trained tribal hornbill monitoring team from each village verified and carried out the verification of the maps made using GPS.

Hornbill Foundation and CED organized a state level workshop with participation from the state authorities and practitioners in 2014 at Thiruvananthapuram with the support of Gram Sabhas and organizations across the state, and it was in continuation with four regional workshops. This was a platform to discuss related issues and to clarify details of implementation. Hornbill foundation had also published a book in regional language, on FRA that included interpretation and translation of FRA 2006, related forms, model maps, claims and FAQ published by Ministry of Tribal Affairs. Original act and rules were also provided in the book as an appendix (Bachan et al., 2013). This was used as a field guide for the officials as well as the stakeholders.

In order to facilitate CFR declarations, CFR mapping and post-CFR agenda in the area, an awareness creation about rules, regulations and responsibilities among the members of Gram Sabha, village level facilitators, DLC and SDLC was necessary. Another attempt was to convert the community level maps submitted by Gram 
Sabhas to scalable maps indicating traditional boundaries recorded through GPS. The community mapping was done by the community using Participatory Rural Appraisal (PRA) methods, and the final map after superimposing it over top sheets was verified in the presence of elders, forest dwellers and honey collectors from the community; officials from the Forest Department and other related departments. The final maps were submitted to the district level ST department along with the claims properly made with forms, resolutions, evidence, list of Gram Sabha members etc. This kind of a careful planning and coordinated effort helped the ethnic community to become a model for effective implementation of FRA, and it was a reiteration on the significant role of local level Gram Sabha in conservation initiatives.

On the other hand, there is hardly any improvement in other parts of Kerala and it was one among the nine poorly FRA implemented states in India (Report of the Working Group (G.O.(Ms)No. $62 / 2008 /$ SCSTDD). To address this, training programmes were conducted by Tribal Department along with UNDP. The experiences of Hornbill Foundation and the resource material prepared were used during the training programmes. Further, Kerala Tribal Department has decided to have rigorous training and action at each district involving all the tribal Grama Sabha members and government officials from Revenue Department, Forest Department, Tribal Department and Panchayath Raj Institutions. This has resulted in a substantial increase in the CFR recognition process and also addressed various challenges in the FRA implementation in Kerala. This has helped the state to progress its achievement into 16 percent of the total target, but the progress of the community right and CFR rights are still very slow (Bachan, 2014). 
Table Progress of CRs and CFRs in Kerala - Data from ST dept. as on 31/01/2016

\begin{tabular}{|c|c|c|c|c|c|c|c|c|c|c|c|}
\hline 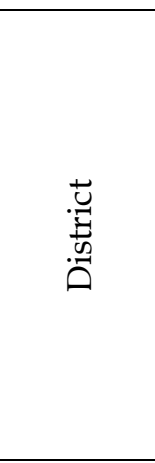 & 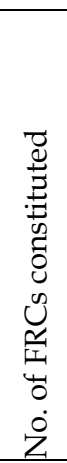 & 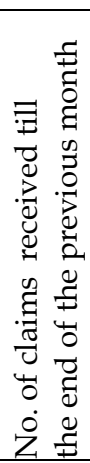 & 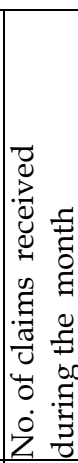 & 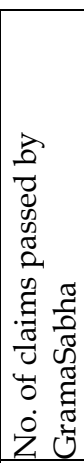 & 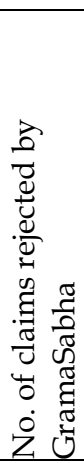 & 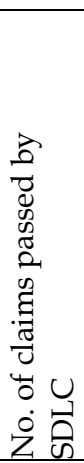 & 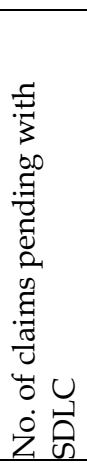 & 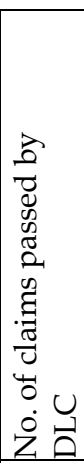 & 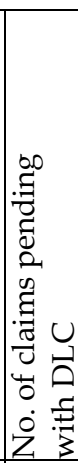 & 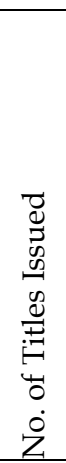 & 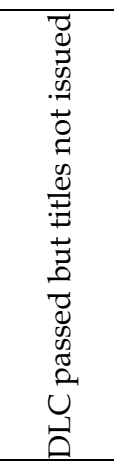 \\
\hline 1 & 2 & 3 & 4 & 6 & 7 & 9 & 11 & 12 & 14 & 15 & $\begin{array}{c}16 \\
(12-15)\end{array}$ \\
\hline $\begin{array}{l}\text { Thiruvan } \\
\text { thapuram }\end{array}$ & 38 & 169 & 0 & 169 & 0 & 0 & 97 & 0 & 0 & 0 & 0 \\
\hline Kollam & 14 & 14 & 0 & 14 & 0 & 14 & 0 & 14 & 0 & 4 & 10 \\
\hline $\begin{array}{l}\text { Pathanam } \\
\text { thitta }\end{array}$ & 18 & 20 & 0 & 20 & 0 & 15 & 0 & 15 & 0 & 0 & 15 \\
\hline Kottayam & 12 & 2 & 0 & 2 & 0 & 2 & 0 & 2 & 0 & 2 & 0 \\
\hline Idukki & 93 & 84 & 0 & 84 & 0 & 84 & 0 & 0 & 84 & 0 & 0 \\
\hline $\begin{array}{l}\text { Erana } \\
\text { kulam }\end{array}$ & 14 & 12 & 0 & 8 & 0 & 8 & 0 & 8 & 0 & 0 & 8 \\
\hline Thrissur & 36 & 52 & 0 & 52 & 0 & 52 & 0 & 52 & 0 & 12 & 40 \\
\hline Palakkad & 143 & 80 & 0 & 71 & 9 & 50 & 21 & 49 & 1 & 0 & 49 \\
\hline $\begin{array}{l}\text { Malap } \\
\text { pauram }\end{array}$ & 32 & 84 & 25 & 109 & 0 & 45 & 54 & 32 & 0 & 0 & 32 \\
\hline Kozhikode & 5 & 6 & 0 & 4 & 0 & 4 & 0 & 4 & 0 & 4 & 0 \\
\hline Wayanad & 109 & 321 & 0 & 151 & 170 & 125 & 13 & 124 & 0 & 124 & 0 \\
\hline Kannur & 57 & 31 & 0 & 31 & 0 & 29 & 0 & 27 & 0 & 0 & 27 \\
\hline Total & 571 & 875 & 25 & 715 & 179 & 428 & 185 & 327 & 85 & 146 & 181 \\
\hline
\end{tabular}

Still, we require constant motivation and informed actions to make sure that FRA is implemented properly and thus respecting the synergy of forest dwellers with their habitat. This does not end with the formation of FRC and the distribution of rights alone. Routine practices of conservation protocols of the community have to be evolved to ensure sustainability. For this, contributions of traditional institutions have a greater role compared to the political and bureaucratic frameworks. The state has to come up with inherent rules and protocols in this regard. At the village level, we 
need to develop an overall database including the skills and qualification of individuals, to ensure the protection and maintenance of community resources in the long run.

\section{Conclusion}

Traditional institutions were strong in keeping conservation as a whole and it has a great history starting from unknown past. But institutions of the state including bureaucracy are appropriating power and control over indigenous institutions or considering them just as agents to carry out the plans envisaged by them. It was this exclusionary principle adopted by the state including forest, revenue and tribal departments that have resulted in the inherent weakness in effectively implementing any scheme and especially the effective conservation programmes. The state induced frameworks were weak in ensuring conservation and sustainability.

Though FRA recognizes the possibility of merging of these traditional institutions with state institutions and that can be visualized as a shifting of our democracy rooted in the exclusive colonial legacy to the inclusive right based democracy. But the progress of FRA implementation and role of different institutional framework indicate that this is not an easy job in a functional way to bring back this real democratic paradigm. The provisions of FRA act envision a broader institutional framework for conservation and governance. It tries to build a platform at the lowest level where we can merge this multiple and overlapping frameworks. If implemented effectively, it would be an ideal model for inclusive right based framework

\section{References}

Bachan A.K.H. (ed) (2014). CFR (FRA 2006) E post CFR - issues, challenges, synergies (assessment of status, requirement for CFRs in Kerala towards preparation of a strategic document for post CFR governance). A state-level consultation report (Draft). Western Ghats Hornbill Foundation \& CED supported by CEPF-ATREE Western Ghats Small Grants 2012.

Bachan A.K.H. \& K. T. Anitha (2013). Involving Local Ethnic Communities in monitoring key biodiversity information and important forest 
resources they depend on in the Anamalai part of Western Ghats, India. Project Report. CEPF-ATREE Western Ghats Small Grants 2011. Bachan A.K.H., Maya Mohan, M.P Shajan, Tintu Kurian \& P.C Rashmi (2013). Forest Right Act \& Community Forest Resource Area Management. Western Ghats Hornbill foundation and CED: Thiruvananthapuram.

Chandi, M. (2008). Tribes of the Anamalais: livelihood and resource-use patterns of communities in the rainforests of the Indira Gandhi Wildlife Sanctuary and Valparai plateau. Mysore, Nature Conservation Foundation Technical Report 16.

Chathukulam, Jos., M.S. John. (2006). "Issues in Tribal Development: The Recent Experience of Kerala." in Tribal Development in India: the Contemporary Debate, edited by Govinda Chandra Rath. Sage Publications: New Delhi.

Ehrenfels, U R. (1952). Kadar of Cochin. Madras, University of Madras.

Gadgil, Madhav., Ramachandra Guha.(1993). The Fissured Land: an ecological history of India. New Delhi, OUP.

Government of Kerala. (2008). Compendium of Government Orders and Circulars on Participatory Forest Management, Thiruvananthapuram, Forest Department.

M, Maya (2013). Tribal Development and Participatory Approach in Kerala: Problems and Prospects (unpublished doctoral dissertation). Loyola College of Social Sciences, University of Kerala, Thiruvananthapuram.

Mudappa, D., TRS Raman. (2007). "Rainforest restoration and wildlife conservation on private lands in the Western Ghats." in Making Conservation Work edited by G Shahabuddin, M Rangarajan. Ranikheth, Permanent Black.

Oommen, T K.(1998). “Changing Paradigm of Development: The Evolving Participatory Society". Journal of Social E Economic Development 1:3545.

Raman, T R S., D. Mudappa. (2003). "Bridging the gap: Sharing responsibility for ecological restoration and wildlife conservation on private lands in the Western Ghats." Social Change 33(2\&3): 129-141.

Sekar, T. 2003. Forest History of Anamalais, Tamil Nadu. Tamil Nadu Forest Department, Coimbatore Circle.

Sundar, N. (2000). "Unpacking the 'Joint' in Joint Forest Management." Development and Change 31(1):255-279.

Thushar Das, Ashish Kothari and Shiba Desor, (2013). A national Report on Community Forest Rights under Forest Rights Act: Status and Issues. An output of the CFR Learning and Advocacy Process. A report by Vasundhara, Kalpavriksh and Oxfam.

Varma, D R., D Churchill, and M Reusser. (2005). Journal on the Cochin State Forest Tramway. 